\title{
Certain Problems of Customary Legal Norms in Family Institutions and Marriage Relations in Sovereign Kyrgyzstan
}

\author{
Zhyldyz Aitbaeva1, Dzhamilia Asanbekova², Kanykei Nurmamat kyzy², \\ Zamirbek Zholdoshbai uulu ${ }^{2}$, Nurzhamal Egemberdieva ${ }^{1}$, Kanzada Karabaeva ${ }^{2}$, \\ Aigul Osmonova2 ${ }^{2}$, Zhypargul Abdullaeva ${ }^{3^{*}}$ (1)
}

${ }^{1}$ Department of Civil Law and Procedure, Osh State University, Osh, Kyrgyzstan

${ }^{2}$ Department of Criminal Law and Procedure, Osh State University, Osh, Kyrgyzstan

${ }^{3}$ Science and Research Department, Osh State University, Osh, Kyrgyzstan

Email: *jypar.science@oshsu.kg

How to cite this paper: Aitbaeva, Z., Asanbekova, D., kyzy, K. N., uulu, Z. Z., Egemberdieva, N., Karabaeva, K., Osmonova, A., \& Abdullaeva, Z. (2021). Certain Problems of Customary Legal Norms in Family Institutions and Marriage Relations in Sovereign Kyrgyzstan. Open Journal of Political Science, 11, 234-241.

https://doi.org/10.4236/ojps.2021.112015

Received: January 2, 2021

Accepted: March 14, 2021

Published: March 17, 2021

Copyright $\odot 2021$ by author(s) and Scientific Research Publishing Inc. This work is licensed under the Creative Commons Attribution International License (CC BY 4.0).

http://creativecommons.org/licenses/by/4.0/

\begin{abstract}
This article is inverstigating certain problems of customary law legal norms in family institutions and marriage relations. Government politics during the establishment of Soviet authority exhibited responsible character associated with massive violations in human rights. All legislative acts in the legal relation were legally insolvent, as they came into conflict with constitutional principles, violating both the rights of the citizens majority individually, and among peoples as a whole. In the period of a social society development, the government policy was inspected, aiming in raising the status of women in society and in the government. Research purpose is to reveal the specific influence of policy pursued by the tsarist government and the Soviet government on the customary law of the Kyrgyzs, in particular in the field of family, marriage relations, legal and social status of women. Research methods are based on the historical, legal and comparative analysis results, on the features of women legal status in family and society during the establishment of the soviet power; identification of the advanced and reasonable trends combination of the tsarist government legislation under traditional view of the Kyrgyzs.
\end{abstract}

\section{Keywords}

Women Rights, Family Institute, Marriage Relations, Common Rights, The Soviet Government, Soviet Legislation, Soviet Authority

\section{Introduction}

Analyzing the women right issues formation and development in the given pe- 
riod, study of colonial conditions pursued by both the tsarist and the Soviet government is of special relevance in politics (Archetti et al., 1987; Aitbaeva, 2017; Aitbaeva \& Aidosova, 2018). It should be noted that the basis of their reforms carried out the task to combine population with territory of Kyrgyzstan and turning into a colony. However, unlike the Soviet government, an integral element of the tsarism politics was a thorough acquaintance, and studies the traditions and customs of the nomadic people. Thus, the tsarist government, represented by the prominent officials, personally took part in the collection and systematization of materials according to the customary law of the Kyrgyzs and Kazakhs (Kuldysheva et al., 2021; Dörre, 2015; Nurysheva et al., 2020). Historical data indicate that tsarist government studied various aspects including family and marriage relations (Preda et al., 2020), criminal legislation, and judicial system (Završnik, 2020). The tsarist government was convinced that the spread of influence over Kyrgyz society was impossible without gaining and strengthening position in the legal sphere, which based on the customary legal provisions. Any changes and reforms carried out in Kyrgyzstan in the interests of colonial politics had to not only take into account this reality, but also assumption. Certain problems referred to the problems of family and marriage relations at the stage of the Soviet government establishment in Kyrgyzstan. Research objectives in this article are women rights, family institute with marriage relations, common rights during the Soviet government legislation.

\section{Customary Law in the Soviet Period}

It should be added to the above that the tsarist government, in contrast to the legal reform carried out by the Soviet state, had a more progressive influence on the common law of the Kyrgyz, enriching it with new positive shades, advanced norms and ideas. As a result of the work done, the norms of the Kyrgyz customary law have been systematized and put into the form of law (Shigaeva et al., 2016). A new juridical system was adopted, consisting of two sections: general imperial courts, guided by national laws and courts of biys, guided by the norms of customary law in resolving cases.

In other words, the general principles of the tsarist policy were that with all the desirability of the cultural impact of "Russian judicial regulations on the life of the local population, beneficial results in this respect can be achieved only through a gradual and careful reduction of the current extensive jurisdiction of the courts". The mutual combination of the people's and Russian courts can only go along the path of "gradual absorption of the first by the second, and by no means through direct intervention of the Russian court in the life and activities of the people's court". Confirmation of the above statement was the adoption of an interim regulation for the management of Kyrgyz oblasts in 1868. According to the rules of the state of affairs, cases classified as criminal under the laws of the Russian government were subject to the jurisdiction of the imperial courts, however, the proceedings of small, mainly civil cases were to be carried out by 
the court of biys. However, by taking into account that the Kyrgyz customary law did not know the cruel punishments existing in the Russian criminal legislation (imprisonment, death penalty, prisons, and self-harm), the tsarist government, when resolving matters in the sphere of marriage and family, was limited by the requirement divorce, or punishment in the form of a fine.

Thus, the positive aspect pursued by the tsarism policy was the avoidance of a conflict between the norms of the Kyrgyz and Russian customary laws, and the combination of the advanced, reasonable tendencies in the tsarist legislation with traditional views of the Kyrgyzs.

Unlike the tsarist government, which retained many customary law norms in the family institute and marriage relations, the Soviet government made an attempt to change the characteristics of the lifestyle, the way of life and culture of local population. According to opinion of the Kazakh scientist Z. Kenzhaliev, the greatest attention was payed to customary law by the Soviet power only in the first ten years of its establishment (Kenzhaliev \& Dauletova, 1993). He asserts that "In further, the Soviet government loses interest in the problem of customary legal culture, reducing it to a struggle with so-called survivor norms of adat". Cancellation of pre-revolutionary laws, in the government's opinion, which are strengthening gender inequality, oppressing women and other forms of restriction and inequality in family and marriage relations, were accompanied by the publication of new acts in accordance with the principles of socialist society. After which, on December 18, 1917, a decree "On civil marriage, on children and on keeping books of acts of civil status" was issued by the Council of People's Commissars and the All-Russian Central Executive Committee of the RSFSR. The decree recognized the legal effect of marriages registered in the registry office, established the basics and procedure for registering marriages on the basis of full equality of rights for women and men. Along with a registered marriage, the decree recognized the conclusion of a civil marriage. However, these forms of marriage were not widespread among the Kyrgyzs and Kazakhs, due to the fact, that they were not applicable to local conditions and did not reflect the internal structure of Kyrgyz and Kazakh society. In the Russian society, recognition of civil marriage was allowed on the equal basis with a registered union, while the Kyrgyz customary law allowed only de facto marital relations. Wherein, the kalym, so undeservedly subjected to violent reconstruction, symbolized just the act of public registration of marriage, accompanied by the performance of certain rites, rituals and celebrations.

\section{Divorce Provisions}

On December 19, 1917, the Council of People's Commissars and the All-Russian Central Executive Committee of the RSFSR issued a decree "On divorce." This decree proclaimed freedom of divorce and established a simplified procedure for divorce based on an application from one of the spouses. It was believed that the law provided an opportunity for a woman married against her will, to indepen- 
dently decide the question of the marriage future. However, the simplified form of divorce by one of the spouses will not provide time given to the parties for reconciliation. Whereas, it is precisely the provision of a certain period of time for reconciliation to the parties was characterized as the main goal of Kyrgyz justice, which contributed to protection of family interests and preserve the tribal community. According to the Soviet government practice on jurisprudence, more than half of divorce issues considered without setting a time limit for reconciliation of spouses. Famous researcher of Kazakh customary law S. Z. Zimanov mentioned: "the task of people's judge was not to check the true reasons for the divorce, but he had to be convinced only of the spouse's real desire to dissolve marriage". The judicial practice of that time indicates that such cases were often considered in the absence of other spouse, and the claim was subject to satisfaction in all occasions (Nurbekov, 1965). In addition, S. Z. Zimanov noted about the rule preserved to this days in contracting marriages, which is absolutely correct in our opinion: “... the rules of the exogamous family were kept within the law, ... it was generally forbidden to marry girls from own families up to seventh generation ... With fragmentation and shrinking of the births and their resettlement in parts among other generations, the adherence of the exogamous family rules was not a difficult matter" (Zimanov, 2009).

As a result, when deciding the divorce cases, ordinary justice was guided not by the impartial application of formal legality, as in a modern government, but by the establishment of justice, understood as the most expedient link in terms of maintaining the viability of the entire society. The struggle against remnants of patriarchal-feudal relations in the field of marriage and family law was waged in subsequent years. A vivid confirmation of this was the publication of the following decrees by the Soviet government: "On the abolition of kalym" in December 28, 1920, "On the law of marriage among the Kyrgyzs" in January 17, 1921, "On the punishment of polygamy among the Kyrgyz" and "On forcing women to marry" from October 24, 1921.

By implementing these decrees, the Soviet government allegedly created conditions for the true liberation of Eastern women: V. I. Lenin wrote "Soviet power is the first and only one in the world destroyed all the old, bourgeois, vile laws that put a woman in unequal position with a man, giving privileges to a man, for example, in the field of marriage law" (Lenin, 1981). Given statement makes it possible to identify the motivation for Soviet government actions, aimed at destroying the national culture of the Kazakh people by radically breaking the entire system of customary law, including in the family law. Considering Kyrgyz customs and traditions as "wild and foul", the country's leadership tried to show that solely thanks to the Soviets authority, these reforms became possible. In reality, the carried out reforms acted as propaganda intended for European governments, as well as the European part of Russia, whose population did not and could not know that the so-called "wild customs" for many centuries were a necessity in the harsh conditions of nomadic and semi-nomadic life of the Kyrgyz society. 
Speaking about radical ways of resolving contradictions between the norms of customary law and Soviet legislation, it should be mentioned about introduction of a criminal law prohibition, which was supposed to eliminate the "survivals" in the field of family and marriage relations of the Kyrgyz people. In particular, in the Instruction of the People's Commissariat of Justice on the application of the Decree "On the abolition of kalym" from February 17, 1921, a punishment was established for persons who violated the ban in the form of imprisonment for up to one year: "The payment and receipt of the bride price is recognized as an act prohibited under penalty of criminal punishment." As an additional punishment, the Decree provided for the confiscation of livestock transferred as kalym and other property from persons who received it in double size. In legal terms, this type of punishment was unjustifiably cruel due to the fact that it did not comply with the principle of proportionality of a socially dangerous act and the punishment for its commission. In fact, imprisonment was provided for a person's attempt to marry in accordance with the customs and traditions of his people.

\section{Polygamy Punishment}

Polygamy was also subjected to criminal liability. The decree "On the punishability of polygamy among the Kyrgyz" from October 24, 1921 provided for imprisonment for up to one year, with the invalidation of a prohibited marriage. Later, in the circular of the People's Commissariat of Justice of the KASSR in March 3, 1925 on the application of Article 232 of the Criminal Code, it was proposed, taking into account the peculiarities of polygamy in the life of $\mathrm{Ka}$ zakhs, to establish the fact of bigamy or polygamy, regardless of the registration of marriage relations in the registry office. In addition, the courts were asked to set in the verdict the period during which a person convicted of polygamy had to change the existing de facto family relationship. Proceeding from the need to protect the material interests of women, the law indicated the need to impose on the convict the obligation to pay them maintenance until they get married or change their material condition, in which they could exist without support.

Often, official documents recorded the successes achieved by the Soviet government in the fight against the customary legal norms of the Kyrgyz in the field of marriage and family relations. Thus, the majority of Soviet authors noted significant achievements in the political and cultural life of Kyrgyzstan as a result of the norms in Decrees "On the abolition of kalym", "On the punishability of polygamy among the Kyrgyz", "On forcing women to marry". These positive developments were confirmed by statistics on the increase number of crimes under consideration. However, from our point of view, the data of such statistics were very dubious, and were disseminated in order to confirm the versatility and effectiveness of the work done in the fight against crimes that constituted "remnants of family life". In fact, the Kyrgyz people for a long time covertly adhered to their traditional norms of customary law, prohibited by Soviet law. For exam- 
ple, as a result of the intensification of the struggle against clan customs, agreements on the payment of kalym begin to be concluded secretly, paid not by cattle, but in cash, in order to avoid punishment for polygamy, people formalized fictitious divorces.

The fight against "harmful customs" continued in the context of forcible transfer politics implementation of nomads to a sedentary lifestyle, "dispossession" of pastoralists. The results of ignoring the rules of nomads civilization for centuries, was an anti-scientific and anti-human politics, which gave rise to a massive hunger of the Kyrgyz population, significant death of its part, as well as migration of Kyrgyz population proportion outside the republic. This migration was driven by despair, hunger, poverty, the complete destruction of the social and economic fundamentals of life.

Summarizing the above, it should be said that the negative influence of the policy pursued by the Soviet government in the 20-30s was a breakdown of family ties and family relations. The government took all measures to destroy the traditional system of law that meets the living conditions of nomads. Restructuration of existing legal relations was carried out without taking into account the traditions and customs of the Kyrgyz people, through gross interference, ignoring their worldview and way of thinking. Therefore, from the need to protect the women rights and interests, the government undertook an offensive, administrative-imperious influence on the norms and institutions of Kyrgyz customary law with the aim of their complete destruction. The process of displacing customary legal norms and institutions was accompanied by rigid and irreconcilable criticism, while in reality the customary legal system of marriage and family law was a self-sufficient mechanism that did not exhaust its regulatory potential for resolving individual family and household matters. Therefore, as Z. Kenzhaliev noted, "the old and new norms could exist in certain periods and within the necessary limits in parallel, complementing each other and serving common goals".

As a result, historical and legal analysis of the women legal status, her role in production and family and household spheres at the stage of the formation of Soviet power in Kyrgyzstan allowed us to draw the following conclusions:

1) The government-legal part of the Russian legislation superstructure had a strong influence on change in norms of the Kyrgyz customary law. However, the legal status of women during the imperial period did not undergo significant changes due to the fact that the tsarist government considered it unacceptable to break the customary legal norms that governed the dominant patriarchal-feudal relations among the Kyrgyz, it tried to adapt to implement its colonial policy. Thus, the operation of customary law as one of the sources of law was allowed up to the 20s of the XIX century.

2) Attempts to change and adapt the common law of the Kyrgyz to the conditions of Soviet power were made by the state in the first years of its establishment. The decrees aimed at combating the remnants of patriarchal-feudal relations actually pursued the goal of demonstrating the priority and superiority of the Soviet way of life and way of life. Ignoring the strong clan traditions that ex- 
isted in the Kyrgyz society turned into tragic consequences not only for women, but also for the entire ethnic group.

\section{Conclusion}

In summary, conditions of the anti-humanistic politics during Soviet government, women children found themselves in extremely difficult material and living conditions, socially unprotected, morally humiliated. Subsequently, the process of reforming the administrative and legal structure of society through the proclamation of slogans aimed at liberalization and freedom of family relations, freedom to conclude and dissolve marriages only increased the social and legal vulnerability of women, mothers and children. The government mechanism for regulating social relations has given rise to such negative phenomena as orphanhood, homelessness, single motherhood and unsecured old age.

The results of the study show that the tsarist government kept many of the norms of customary law in the field of family and marriage relations, and the Soviet government attempted to change the peculiarities of the way of life and culture of native population.

Finally, the historical and legal analysis of women legal status, role in production and family and household spheres at the stage of the Soviet power formation in Kyrgyzstan allowed us to draw the following conclusions:

1) The state-legal part of the superstructure of Russian legislation had a strong influence on the change in the norms of the Kyrgyz customary law. However, the legal status of women during the imperial period did not undergo significant changes because the tsarist government considered it unacceptable to break the customary legal norms that governed dominant patriarchal-feudal relations among the Kyrgyzs, it tried to adapt them to implement colonial policy. Thus, the operation of customary law as one of the sources of law was allowed until the 20s of the XIX century.

2) Attempts to change and adapt the common law of Kyrgyzs according to conditions of the Soviet authority were made by the government in the first years of establishment. The decrees aimed to combat the remnants of patriarchal-feudal relations, actually pursued the goal of demonstrating the priority and superiority of the Soviet government customs and way of life. Ignoring the strong clan traditions that existed in Kyrgyz society turned into tragic consequences not only for women, but also for the entire ethnic group. In the conditions of anti-humanistic policy of the Soviet government, women and children found themselves in extremely difficult living conditions, socially unprotected and morally humiliated. Subsequently, the process of reforming the administrative and legal structure of society through the proclamation of slogans aimed at liberalizing and freedom of family relations, freedom to conclude and dissolve marriage relations only increased the social and legal vulnerability of mothers, children and women. The government mechanism for regulating social relations has given rise to such negative phenomena as orphanhood, homelessness, single motherhood and unsecured old age. 


\section{Conflicts of Interest}

The authors declare no conflicts of interest regarding the publication of this paper.

\section{References}

Aitbaeva, Z. S., \& Aidosova, C. A. (2018). Problems of Regulation of Protection and Compliance, Labor Rights of Women in the Kyrgyz Republic. Bulletin of the Branch of the Federal State Budgetary Educational Institution of Higher Education "Russian State Social University", 2, 14-17.

Aitbaeva, Z. S. (2017). Women Rights in the Kyrgyz Republic in the Politics Sphere. Bulletin of the Branch of the Federal State Budgetary Educational Institution of Higher Education "Russian State Social University", 16, 11-17.

Archetti, E. P., Cammack, P., \& Roberts, B. (1987). Colonial Politics. In E. P. Archetti, P. Cammack, \& B. Roberts (Eds.), Latin America, Sociology of "Developing Societies". London: Palgrave. https://doi.org/10.1007/978-1-349-18629-7

Dörre, A. (2015). Promises and Realities of Community-Based Pasture Management Approaches: Observations from Kyrgyzstan. Pastoralism, 5, Article No. 15. https://doi.org/10.1186/s13570-015-0035-8

Kenzhaliev, Z. Z, \& Dauletova, D. O. (1993). Kazakh Customary Law in the Conditions of Soviet Power (1917-1937) (p. 141). Almaty: Gylym.

Kuldysheva, G., Minbaev, S., Paraidin uulu, S., Mirzaeva, A., Atantaev, A., Mamazakirov, R., Kuldyshev, A., Abdullaeva, Z., \& Toktobaeva, E. (2021). Kyrgyz Customary Law Development. Open Journal of Social Sciences, 9, 321-327.

https://doi.org/10.4236/jss.2021.91023

Lenin, V. I. (1981). Complete Collected Works, Part 39 (p. 582). Moscow.

Nurbekov, K. N. (1965). Kyrgyz SSR Government and Law History. Kyrgyz State University, Frunze: Mektep, Issue 1, p. 155.

Nurysheva, G., Amrebayeva, Z., \& Amrebayev, A. (2020). The Kazakh Ethical Tradition and Anti-nuclear Ethics. In G. Bombaerts, K. Jenkins, Y. Sanusi, \& W. Guoyu (Eds.), Energy Justice Across Borders (pp. 69-87). Cham: Springer.

https://doi.org/10.1007/978-3-030-24021-9 4

Preda, M., Mareci, A., Tudoricu, A., Taloș, A.-M., Bogan, E., Lequeux-Dincă, A. I., \& Vijulie, I. (2020). Defining the Concept of Family through the Lens of Fertile-Aged Women in Bucharest, Romania-between Traditionalism and Inclusion. Sustainability, 12, 2691. https://doi.org/10.3390/su12072691

Shigaeva, J., Hagerman, S., Zerriffi, H., Hergarten, C., Isaeva, A., Mamadalieva, Z., \& Foggin, M. (2016). Decentralizing Governance of Agropastoral Systems in Kyrgyzstan: An Assessment of Recent Pasture Reforms. Mountain Research and Development, 36, 91-101. https://doi.org/10.1659/MRD-JOURNAL-D-15-00023.1

Završnik, A. (2020). Criminal Justice, Artificial Intelligence Systems, and Human Rights. ERA Forum, 20, 567-583. https://doi.org/10.1007/s12027-020-00602-0

Zimanov, S. Z. (2009). The Social System of Kazakhs in the First Half of the 19th Century and the Bukeev Khanate (p. 400). Almaty: Publishing House Arys. 